\title{
Size resolved mass concentration and elemental composition of atmospheric aerosols over the Eastern Mediterranean area
}

\author{
J. Smolík ${ }^{1}$, V. Ždímal ${ }^{1}$, J. Schwarz ${ }^{1}$, M. Lazaridis ${ }^{3}$, V. Havránek ${ }^{2}$, K. Eleftheriadis ${ }^{4}$, N. Mihalopoulos ${ }^{5}$, C. Bryant ${ }^{6}$, \\ and I. Colbeck ${ }^{6}$ \\ ${ }^{1}$ Institute of Chemical Process Fundamentals, ASCR, Prague, Czech Republic \\ ${ }^{2}$ Nuclear Physics Institute AS CR, Prague, Czech Republic \\ ${ }^{3}$ Technical University of Crete, Department of Environmental Engineering, 73100 Chania, Greece \\ ${ }^{4}$ Institute of Nuclear Technology \& Radiation Protection, N.C.S.R. Demokritos, 15310 Ag. Paraskevi, Attiki, Greece \\ ${ }^{5}$ Environmental Chemical Processes Lab. (ECPL), Department of Chemistry, University of Crete 71409 Heraklion, Greece \\ ${ }^{6}$ Department of Biological Sciences, University of Essex, UK
}

Received: 24 March 2003 - Published in Atmos. Chem. Phys. Discuss.: 19 May 2003

Revised: 1 December 2003 - Accepted: 3 December 2003 - Published: 9 December 2003

\begin{abstract}
A Berner low pressure impactor was used to collect size-segregated aerosol samples at Finokalia, located on the north-eastern coast of Crete, Greece during July 2000 and January 2001. Several samples were also collected during the summer campaign aboard the research vessel "AEGAIEO" in the Aegean Sea. Gravimetric analysis and inversion techniques yielded daily PM1 and PM10 mass concentrations. The samples were also analysed by PIXE giving the elemental size distributions of $\mathrm{Al}, \mathrm{Si}, \mathrm{K}, \mathrm{Ca}, \mathrm{Ti}, \mathrm{Mn}, \mathrm{Fe}, \mathrm{Sr}, \mathrm{S}, \mathrm{Cl}$, $\mathrm{Ni}, \mathrm{V}, \mathrm{Cu}, \mathrm{Cr}, \mathrm{Zn}$, and $\mathrm{Pb}$. The crustal elements and sea-salt had a unimodal supermicron size distribution. Sulphur was found predominantly in submicron fractions. $\mathrm{K}, \mathrm{V}$, and $\mathrm{Ni}$ exhibited a bimodal distribution with a submicron mode produced by forest fires and oil combustion. The anthropogenic elements had broad and not well-defined distributions. The time series for PM1 and PM10 mass and elemental concentrations showed both daily and seasonal variation. Higher mass concentrations were observed during two incursions of Saharan dust, whilst higher concentrations of $\mathrm{S}, \mathrm{Cu}, \mathrm{Zn}$, and $\mathrm{Pb}$ were encountered in samples collected in air masses arriving from northern Greece or the western coast of Turkey. Elevated concentrations of chlorine were found in samples with air masses either originating above the Atlantic Ocean and arriving at Finokalia via western Europe or recirculating over the western coast of the Black Sea.
\end{abstract}

Correspondence to: $\mathrm{M}$. Lazaridis

(lazaridi@mred.tuc.gr)

\section{Introduction}

Intensive aerosol and gaseous pollutant measurement campaigns have been performed at Finokalia on the island of Crete (Greece) in combination with sea-based research vessel measurements in the eastern part of the Mediterranean area as part of the SUB-AERO project. The measurements were performed with the participation of 9 European research institutions, and together with regional/mesoscale/subgrid modelling studies were utilized to investigate the dynamics/characteristics of photochemical and fine particle pollutants in the Mediterranean area. The research work was performed under the auspices of the European Union Fifth Framework Programme (project SUB-AERO).

Under this research framework gaseous phase measurements for a number of photo-oxidants, fine particle concentration measurements and detailed PM1 and PM10 particulate matter characterisation were carried out in the eastern Mediterranean area during summer 2000 and winter 2001. The experimental data were compared with results from modelling studies on the dynamics of photochemical gaseous species and particulate matter.

The Mediterranean Sea is situated to the south of the highly populated European countries with industrial, semiindustrial, and rural economies, and to the north of Africa which includes the Sahara desert. A detailed wind trajectory analysis shows that more than $60 \%$ of air masses which arrive in the eastern Mediterranean come from the N-NW and $13-16 \%$ from the Sahara (Guerzoni et al., 1990). Air masses from the N-NW contain particles emitted or derived from industrial and urban sources; while those from Sahara carry predominantly mineral dust. Transport of Saharan dust occurs mostly during the spring and summer and 


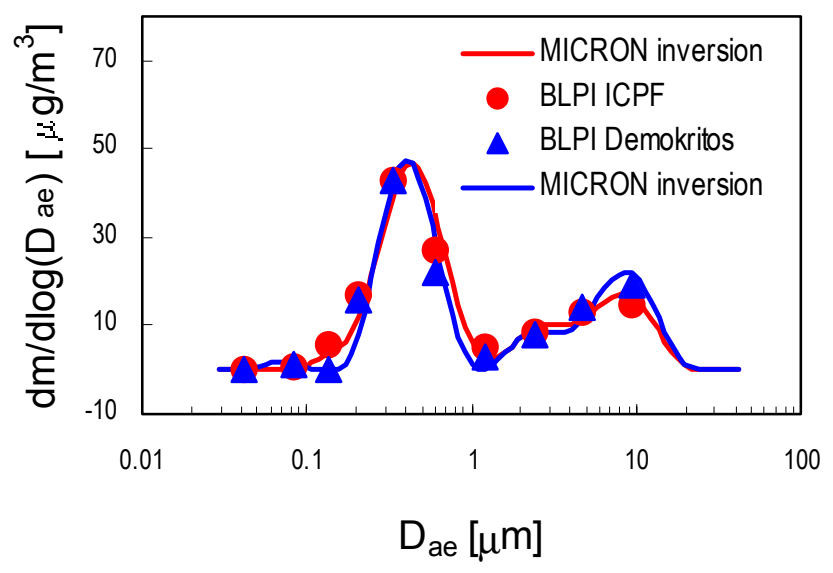

Fig. 1. Intercomparison of two BLPI cascade impactors. The raw mass size data were inverted into smooth mass size distributions by the MICRON code.

causes sporadic crustal aerosol pulses to the Mediterranean area (e.g. Bergametti et al., 1989b; Moulin et al., 1998). On the other hand, precipitation scavenging during the rainy season between October and May reduces aerosol concentrations (e.g. Dulac et al., 1987; Bergametti et al., 1989a). The summer time is also characterised by low-inversion layers and strong sunlight, causing photochemical smog. Moreover, forest fires, which occur during the summer months in the Mediterranean region and in North Africa, increase black carbon and fine particle emissions. Thus, the Mediterranean Sea constitutes an area where atmospheric particles originating from continental natural and anthropogenic sources, marine sources and gas-to-particle conversion are present at all times. Furthermore, specific meteorological conditions result in a high temporal variability of aerosol concentrations. Consequently, the Mediterranean area offers unique conditions for aerosol modelling/measurement studies.

The majority of the studies on the chemical composition of Mediterranean aerosol have been conducted in the western and north-western region (e.g. Dulac et al., 1987; Bergametti et al., 1989a, b; Dulac et al., 1989; Migon et al., 1991; Migon et al., 1993; Sandroni and Migon, 1997) or on the eastern coast including Turkey and Israel (e.g. Mamane et al., 1980; Ganor et al., 1991; Kubilay et al., 1994; Luria et al., 1996; Maenhaut et al., 1999; Güllü et al., 2000; Yatin et al., 2000; Erduran and Tuncel, 2001). However relatively few studies have been undertaken in the southern part of the eastern Mediterranean and Greece (e.g. Chester et al., 1993; Mihalopoulos et al., 1997; Danalatos and Glavas, 1999; Chabas and Lefèvre, 2000). Here we report on atmospheric aerosol measurements on the island of Crete (south-eastern Mediterranean) using cascade impactors and the characterisation of the collected particulate matter. Emphasis is placed on the mass and elemental size distributions and the temporal variability of PM1 and PM10.

\section{Experimental}

\subsection{Sampling site}

Aerosol samples were collected on Crete during the periods 10-31 July 2000 and 7-14 January 2001. According to the analysis of 10 years air mass back trajectories (WMO, 1985; Guerzoni et al., 1990; Chester et al., 1993) 39\% of air masses arrive at Crete from the north across Greece, eastern Europe and the former USSR, 28\% of air masses arrive from the west-northwest, crossing western Europe, $16 \%$ come from the south, transporting aerosol from the Sahara and North Africa deserts, and 17\% come from the east crossing the Middle East desert regions. Mihalopoulos et al. (1997) report similar figures. The main sampling site was located at Finokalia on the island of Crete. Finokalia $\left(35^{\circ} 19^{\prime} \mathrm{N}\right.$, $25^{\circ} 40^{\prime} \mathrm{E}$ ) is a coastal remote site, east of Heraklion on the top a hill $(\sim 150 \mathrm{~m}$ a.s.l. $)$ facing the sea within the sector of $270^{\circ}$ to $90^{\circ}$. In addition samples of atmospheric aerosol were also collected during the period 25-29 July 2000 aboard the research vessel "AEGAIEO". The vessel cruised in the Aegean Sea along selected tracks mainly upwind the Finokalia site, as indicated by forward and back trajectory modelling with the Finokalia sampling site as the end point.

\subsection{Sampling}

Samples of atmospheric particulate matter were collected and size-segregated into 10 size fractions by two Berner type low pressure cascade impactors BLPI 25/0,018/2, one from ICPF Prague and the second from NCSR "Demokritos", Athens. The impactors were used alternately at Finokalia station during the period 10-19 July 2000. After that measurements at Finokalia continued with the impactor from ICPF and the impactor from "Demokritos" was used aboard the "AEGAIEO". Both impactors were used alternately during the winter campaign (7-14 January 2001). In order to determine the real cut diameters and shapes of the collection efficiency curves the Prague impactor was calibrated at the Finnish Meteorological Institute by the method described by Hillamo and Kauppinen (1991). It was found that the real cut diameters $\left(\mathrm{D}_{50}\right.$ values) for stages $1-10$ were 0.026 , $0.062,0.110,0.173,0.262,0.46,0.89,1.77,3.4$, and $6.8 \mu \mathrm{m}$. Further, it was found that all stages of impactor have reasonably sharp collection efficiency curves, which makes the impactor response suitable for use with a data inversion technique (Hillamo et al., 1999). Before both campaigns the impactors were compared during 2-day measurements of mass size distribution of urban aerosol in Athens. For this purpose both impactors were connected in parallel to the same vacuum pump and two 24-hour samples were taken. The result of the intercomparison is shown in Fig. 1, where Dae is the geometric mean aerodynamic diameter. As can be seen the instruments were practically identical. 
Sampling at Finokalia was carried out on the roof of small building. The impactor, with an inlet providing approximately $15 \mu \mathrm{m}$ upper cut-off particle size, was positioned at a height of about $3 \mathrm{~m}$ above the ground. To reduce particle bounce samples were deposited on Nuclepore polycarbonate foils greased with Apiezon L vacuum grease. Sampling was carried out over approximately 24 -h intervals with a flow rate of $251 / \mathrm{min}$ (in some cases the real time was shorter due to electrical current interruptions). The first sample was taken from 10 July 2000 (10:00) to 11 June 2000 (10:00) local time. Due to some technical problems samples on the boat were not taken at standard times, as at Finokalia, and sampling times were usually shorter. In total 5 samples were collected aboard the research vessel over the following time intervals 25 July (23:10)-26 July (09:53), 26 July (11:15)-27 July (10:20), 27 July (11:12)-28 July (09:15), 28 July (10:45)29 July (01:15), and on 29 July between 09:00-18:43. During the winter sampling started at about 14:00. Thus the first sample was taken between 7 January 2001 (14:00) and 8 January 2001 (14:00). In total 21 samples from the summer campaign, 5 samples from the research vessel and 7 samples from the winter measurements were obtained, with each sample consisting of 10 size fractions.

\subsection{Gravimetric analysis}

The mass size distributions were obtained from the mass of particulate matter deposited on the individual stages of the impactor, volume flow rate of aerosol and total time of sampling. The electronic microbalances ATI Cahn and Sartorius BP211D with a maximum attainable precision of $10 \mu \mathrm{g}$ were used for weighing the aerosol samples from the summer campaign. During the winter campaign Sartorius M5P-000V001 electronic microbalances with maximum attainable precision of $1 \mu \mathrm{g}$ were used. Foils were transported from the sampling site in Petri dishes and equilibrated in the weighing room for at least $24 \mathrm{~h}$ before weighing at conditions R.H. $56 \pm 13 \%$ and temperature $24.7 \pm 1.0^{\circ} \mathrm{C}$ (summer), R.H. $62.8 \pm 2.5 \%$ and temperature $26.8 \pm 1.0^{\circ} \mathrm{C}$ (research vessel) and R.H. 69.2 \pm 1.8 and temperature $21.4 \pm 0.8$ (winter). Internal calibration of the balance was performed regularly, at least once at the beginning of each weighing session. To check reproducibility of the weighing procedure, a control aluminum foil was weighed at least once during each weighing session. Before and after each weighing session another control substrate (blank made of the same polycarbonate foil processed the same way but without a sample) was weighed to check the influence of possible temperature and RH fluctuations.

\subsection{Elemental analysis}

All samples were analysed by particle-induced X-ray emission (PIXE). The analyses were performed on the $3 \mathrm{MeV}$ Van de Graaff electrostatic accelerator at the Nuclear Physics In- stitute in Řež (Prague). The samples consisted of annular deposits of individual spots, with the number of spots depending on the stage. Usually, six spots from stage 1, two spots from stage 2, and one spot from stages 3-10 were analysed. To obtain the elemental concentrations for individual size fractions, the results of the analysis were related to the actual number of spots on each stage. Two proton beam energies of $1.31 \mathrm{MeV}$ and $2.35 \mathrm{MeV}$ were used to irradiate the samples. A $3 \mathrm{~mm}$ diameter collimator for the proton beam was chosen for stages 1 to 9 , whilst stage 10 was analysed with an $8 \mathrm{~mm}$ collimator. A proton fluence of about $10 \mu \mathrm{C}$ and $50 \mu \mathrm{C}$ were used for the $1.31 \mathrm{MeV}$ and $2.35 \mathrm{MeV}$ measurements, respectively. The typical time for one irradiation was about 5 min. To reduce the intense low energy X-rays from sample for the $2.35 \mathrm{MeV}$ irradiation a $1 \mathrm{~mm}$ polyethylene absorption filter was used. In samples from the summer campaign $\mathrm{Al}$, $\mathrm{Si}, \mathrm{K}, \mathrm{Ca}, \mathrm{Ti}, \mathrm{Mn}, \mathrm{Fe}, \mathrm{Sr}, \mathrm{S}, \mathrm{Cl}, \mathrm{Ni}, \mathrm{V}, \mathrm{Cu}, \mathrm{Cr}, \mathrm{Zn}$, and $\mathrm{Pb}$ were determined. During the winter campaign polycarbonate foils with low blank of $\mathrm{Br}$ were used, thus allowing the determination of $\mathrm{Br}$. Elements up to Ti were determined from 1.31 MeV irradiation, whilst $2.35 \mathrm{MeV}$ irradiation was used for the remainder. The influence of the observed matrix effect due to the deposit thickness was corrected using the Equivalent Layer Thickness Model (Havránek et al., 1999). The ratio of the Fe signals from 1.35 MeV and 2.35 MeV irradiations was used to estimate the effective thickness of aerosol deposit for individual spots. The total combined relative uncertainty of elemental concentrations determined on BLPI samples was estimated to be 5-10\% for the high $\mathrm{Z}$ elements (Fe and above) and 10-20\% for low Z elements (Havránek et al., 2002).

\section{Results and discussion}

\subsection{Mass size distributions}

The mass size distributions were predominantly bimodal with mode mean diameters around 0.4 and $5 \mu \mathrm{m}$ and a minimum between both modes at around $1 \mu \mathrm{m}$. The raw mass concentrations derived for each impactor stage were inverted into smooth mass size distributions by the MICRON code (Wolfenbarger and Seinfeld, 1990). The inverted distributions were integrated to obtain PM1 and PM10 mass concentrations. The time series of PM1 and PM10 for both summer and winter campaigns are shown in Fig. 2. As can be seen both PM1 and PM10 mass concentrations show short-term (daily) and long-term (seasonal) variations. In our case the daily PM10 mass concentration, measured at Finokalia during the summer, ranged from 20.7 to $40 \mu \mathrm{g} / \mathrm{m}^{3}$ between the 10 and 18 July 2000. For the next six days it was virtually constant being approximately $29 \mu \mathrm{g} / \mathrm{m}^{3}$. On the 27 July it increased to $67.2 \mu \mathrm{g} / \mathrm{m}^{3}$ and finally fell to 37 on 30 July. A similar increase of PM10 concentration was observed in samples collected aboard the boat, with a maxi- 


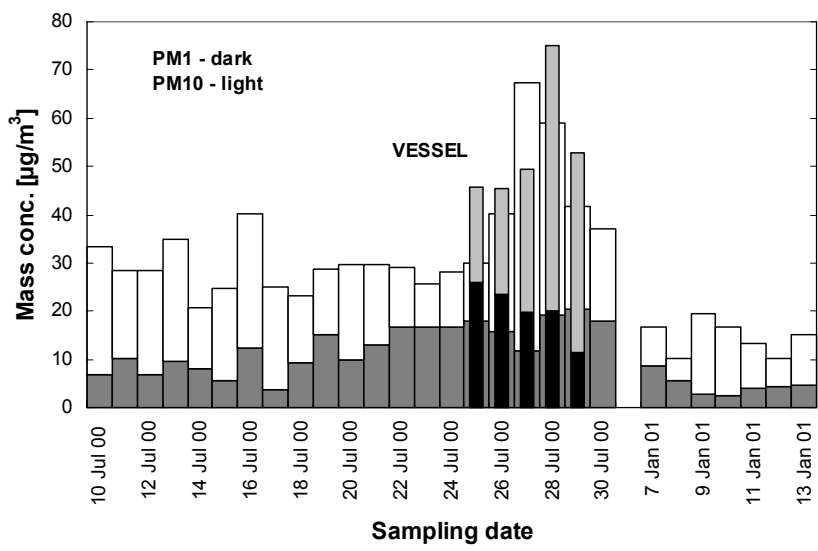

Fig. 2. Daily PM1 and PM10 mass concentrations at Finokalia and aboard the "AEGAIEO".

mum of $75.1 \mu \mathrm{g} / \mathrm{m}^{3}$ (28 July 2000). The daily PM1 mass concentration, measured during the summer, ranged from 3.7 to $20.2 \mu \mathrm{g} / \mathrm{m}^{3}$ and from 11.6 to $25.9 \mu \mathrm{g} / \mathrm{m}^{3}$ at Finokalia and aboard the boat, respectively. During the winter the daily PM1 and PM10 concentrations varied from 2.4 to $8.6 \mu \mathrm{g} / \mathrm{m}^{3}$ and from 10.1 to $19.5 \mu \mathrm{g} / \mathrm{m}^{3}$, respectively. The short-term variation in aerosol mass and composition, is observed frequently in the Mediterranean area and surrounding regions. It is caused mainly by changes in air mass transport arriving from different sectors toward the sampling point (e.g. Dulac et al., 1987; Bergametti et al., 1989a,b; Guerzoni et al., 1990; Ganor et al., 1991; Hacisalihoğlu et al, 1991, 1992; Migon et al., 1993; Kubilay et al., 1994, 1995; Luria et al., 1996; Mihalopoulos et al., 1997; Sandroni and Migon, 1997; Güllü et al., 2000; Danalatos and Glavas, 1999; Chabas and Lefèvre, 2000; Yatin et al., 2000; Erduran and Tuncel, 2001).

To estimate the effect of air mass transport we computed the backward trajectories (HYSPLIT4 Trajectory Model) with $6 \mathrm{~h}$ time steps $72 \mathrm{~h}$ backward in time for two transport layers $300-2000 \mathrm{~m}$ and $1500-3000 \mathrm{~m}$ ). The results showed that the air masses arriving in Crete changed direction several times between the north and west during the first period (10-18 July 2000). Higher PM10 concentrations were observed with air masses originating over the Atlantic Ocean and western Europe (10, 13 and 16 July 2000). The relatively constant PM10 concentration observed during 19-25 July 2000 corresponded to air masses originating from the west coast of the Black Sea. The peak PM10 mass concentrations, observed during the end of the summer campaign, corresponded to air masses from North Africa. During the winter campaign higher mass concentrations were observed with air masses originating over the Atlantic Ocean and arriving via Northern Africa and the Mediterranean Sea (9 January 2001). Higher mass concentrations were also observed for air masses originating from southern Greece and the Ionian Sea, that recirculated above Crete (7 January 2001) or originated above the Mediterranean Sea and recirculated over the North Africa coast. However, for similar meteorological conditions low aerosol mass concentrations were also found (8 January 2001).

The long-term (seasonal) variation results in different average aerosol concentrations being observed during the different seasons. In our case the geometric mean PM1 and PM10 mass concentrations, measured at Finokalia during the summer, were 11.44 and $32.09 \mu \mathrm{g} / \mathrm{m}^{3}$, respectively. Corresponding winter mass concentrations were 4.22 and $14.17 \mu \mathrm{g} / \mathrm{m}^{3}$, respectively. Similar seasonal variability was observed by other authors (e.g. Bergametti et al., 1989a,b; Güllü et al., 2000; Chabas and Lefèvre, 2000) for aerosol concentrations measured in the Mediterranean region. This may be attributed to scavenging by precipitation during transport from source areas. This is more frequent during the rainy period in autumn and winter.

\subsection{Elemental size distributions}

As already mentioned in previous paragraphs $\mathrm{Al}, \mathrm{Si}, \mathrm{K}, \mathrm{Ca}$, $\mathrm{Ti}, \mathrm{Mn}, \mathrm{Fe}, \mathrm{Sr}, \mathrm{S}, \mathrm{Cl}, \mathrm{Ni}, \mathrm{V}, \mathrm{Cu}, \mathrm{Cr}, \mathrm{Zn}$, and $\mathrm{Pb}$ were determined in BLPI samples using PIXE. In addition polycarbonate foils with low blank of $\mathrm{Br}$ were used during the winter campaign thus allowing $\mathrm{Br}$ to be determined. Typically samples collected on stages 1-6 (i.e. with particles $<1 \mu \mathrm{m}$ in diameter) were black indicating the presence of soot from fossil fuel combustion. The samples with coarse particles were beige in colour corresponding to mineral dust. The raw elemental concentrations for each impactor stage were inverted into smooth elemental size distributions by means of the MICRON code and three types of elemental size distribution were found. Practically monomodal distributions with particle size $>1 \mu \mathrm{m}$ and a mode centered at about $4 \mu \mathrm{m}$ were typical for $\mathrm{Al}, \mathrm{Si}, \mathrm{Ca}, \mathrm{Ti}, \mathrm{Mn}, \mathrm{Fe}$, and $\mathrm{Sr}$, though also multimodal distribution of $\mathrm{Al}$ and $\mathrm{Si}$ was observed during the winter. Also $\mathrm{Cl}$ exhibited monomodal distribution with particle size $>1 \mu \mathrm{m}$ and a mode around $5 \mu \mathrm{m}$. S, Br, K, V, and $\mathrm{Ni}$ exhibited bimodal distributions with modes at around 0.3 and $3 \mu \mathrm{m}$ and minimum at about $1 \mu \mathrm{m}$. $\mathrm{Cu}, \mathrm{Cr}, \mathrm{Zn}$, and $\mathrm{Pb}$ showed rather flat multimodal distributions, which were centered at about $1 \mu \mathrm{m}$. Typical elemental distributions of $\mathrm{Si}, \mathrm{K}$, $\mathrm{Cl}$, and $\mathrm{S}$ for different meteorological conditions are shown in Figs. 3a-c. The distributions obtained in summer include air masses coming first from the area of the western Coast of the Black Sea and later on from Libya (12 July 2000), air masses originating above the Atlantic Ocean and advected across western Europe and southern Italy (17 July 2000), air masses originating above western Ukraine and Romania and arriving to Crete from north across Turkey (22 July 2000), and air masses arriving from the North,with long residence times over the Aegean Sea (28 July 2000). Figure 3b compares the distributions obtained on 28 July 2000 with the corresponding distributions measured aboard the AEGAIEO. The distributions obtained in winter (Fig. 3c) include air masses arriving with low wind speeds from the area of south- 

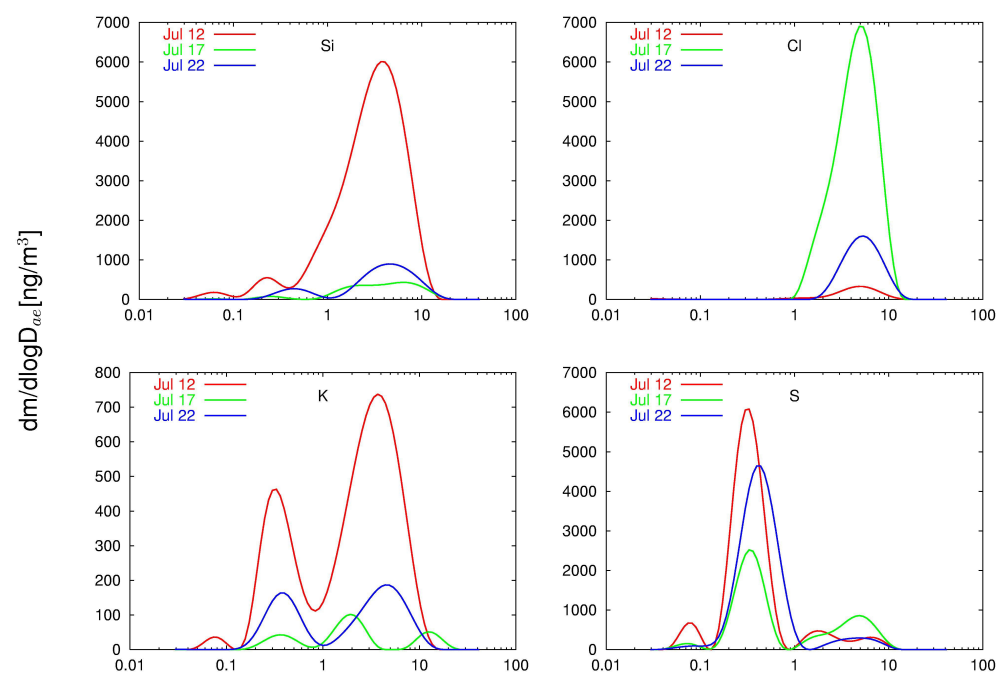

(a)
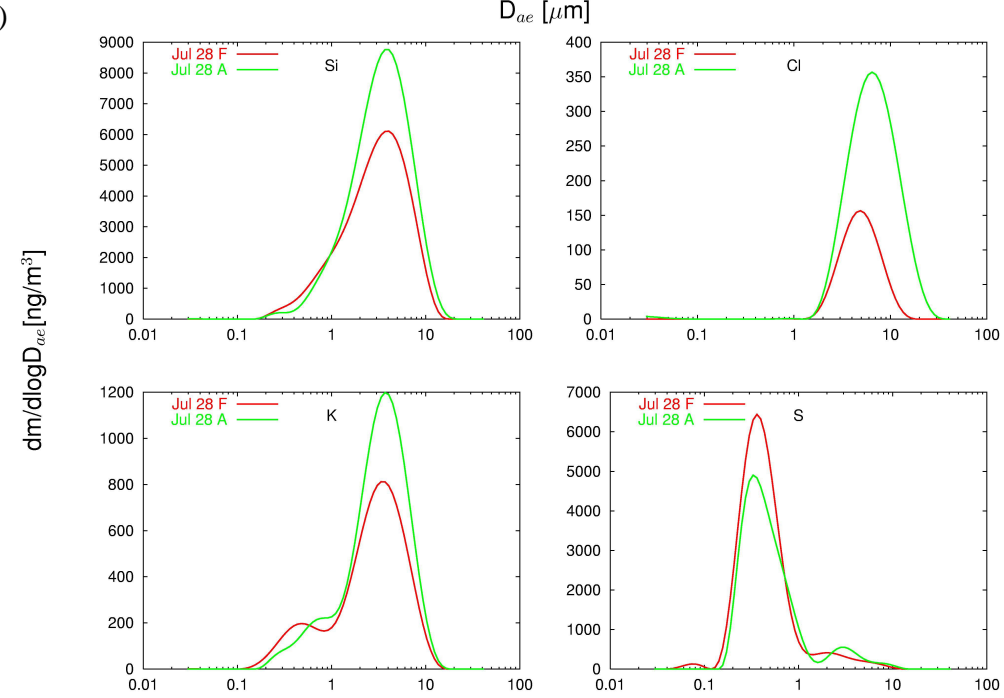

(b)
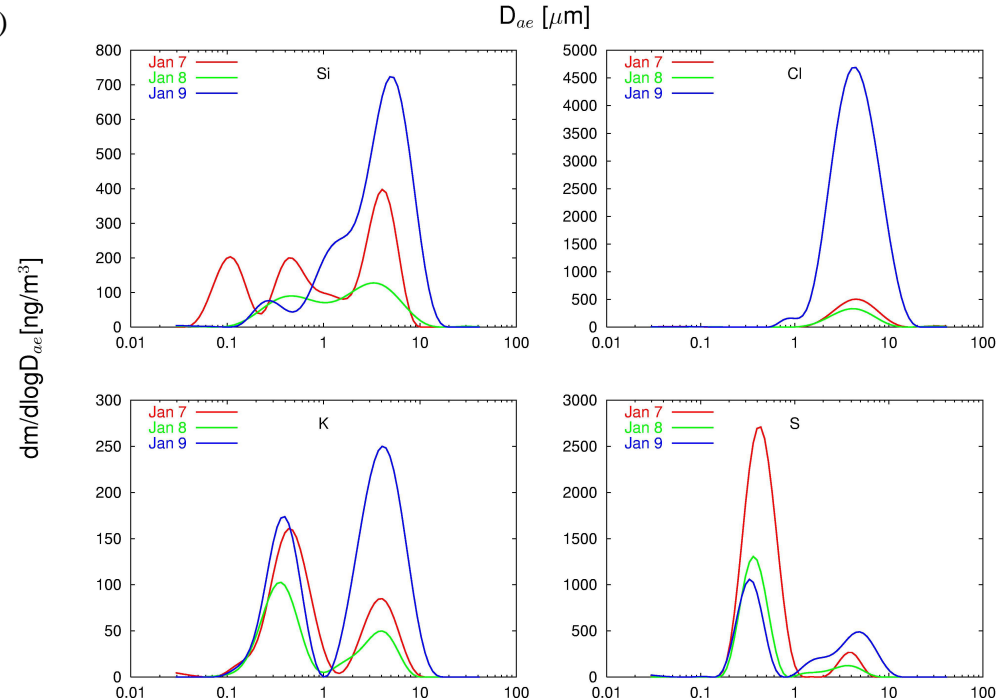

(c)

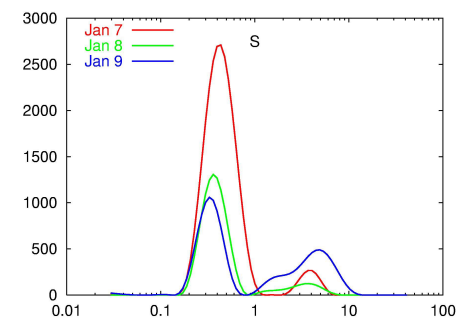

$\mathrm{D}_{a e}[\mu \mathrm{m}]$

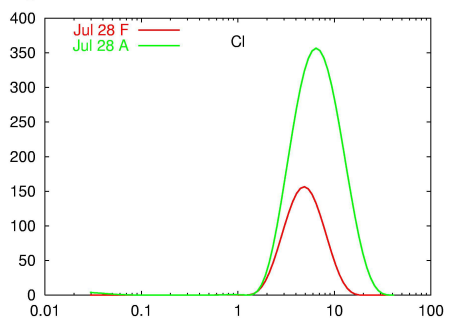

Fig. 3. Comparison of elemental size distributions of $\mathrm{Si}, \mathrm{K}, \mathrm{Cl}$, and $\mathrm{S}$ obtained at different meteorological conditions in summer (a) at Finokalia station (F) (12, 17 and 22 July 2000), (b) at Finokalia station and aboard the "AEGAIEO" (A) (28 July 2000) and (c) at Finokalia station in winter $(7,8$ and 9 January 2001). 
Table 1. Arithmetic mean mass $\left(\mu \mathrm{g} / \mathrm{m}^{3}\right)$ and elemental $\left(\mathrm{ng} / \mathrm{m}^{3}\right)$ concentrations in PM1 and PM10 fractions of atmospheric aerosol collected at Finokalia during the summer (10-31 July 2000) and winter (7-14 January 2001) campaigns.

\begin{tabular}{ccccccccc}
\hline & \multicolumn{4}{c}{ PM1 } & \multicolumn{5}{c}{ PM10 } \\
\multicolumn{4}{c}{ Summer } & \multicolumn{2}{c}{ Winter } & \multicolumn{2}{c}{ Summer } & \multicolumn{2}{c}{ Winter } \\
& Mean & s.d. & Mean & s.d. & Mean & s.d. & Mean & s.d. \\
\hline Mass & 12.5 & 4.9 & 4.6 & 2.1 & 33.5 & 11.4 & 14.5 & 3.5 \\
$\mathrm{Al}$ & 87.2 & 91.0 & 40.5 & 24.9 & 501 & 658 & 112 & 53 \\
$\mathrm{Si}$ & 219 & 256 & 76.3 & 43.1 & 1692 & 1855 & 293 & 160 \\
$\mathrm{~S}$ & 1990 & 730 & 619 & 262 & 2268 & 652 & 766 & 221 \\
$\mathrm{Cl}$ & 1.9 & 2.5 & 11.0 & 12.8 & 1318 & 1257 & 1281 & 1143 \\
$\mathrm{~K}$ & 101 & 67 & 84.2 & 38.5 & 329 & 223 & 148 & 61 \\
$\mathrm{Ca}$ & 35.4 & 43.3 & 12.5 & 17.6 & 704 & 559 & 169 & 85 \\
$\mathrm{Ti}$ & 4.3 & 5.5 & 0.42 & 0.36 & 41.1 & 55.4 & 3.8 & 3.9 \\
$\mathrm{~V}$ & 4.7 & 2.2 & 2.7 & 1.4 & 6.9 & 3.3 & 3.1 & 1.6 \\
$\mathrm{Cr}$ & 0.52 & 0.35 & 0.24 & 0.17 & 1.1 & 0.8 & 0.38 & 0.26 \\
$\mathrm{Mn}$ & 1.4 & 0.9 & 0.29 & 0.13 & 8.5 & 8.3 & 0.86 & 0.49 \\
$\mathrm{Fe}$ & 37.7 & 52.2 & 5.5 & 1.8 & 422 & 530 & 44.8 & 35.2 \\
$\mathrm{Ni}$ & 1.6 & 0.7 & 1.2 & 0.4 & 2.1 & 1.0 & 1.6 & 0.4 \\
$\mathrm{Cu}$ & 0.50 & 0.37 & 0.31 & 0.1 & 1.7 & 0.9 & 0.52 & 0.10 \\
$\mathrm{Zn}$ & 6.3 & 3.4 & 2.3 & 1.1 & 11.2 & 5.2 & 3.6 & 2.0 \\
$\mathrm{Sr}$ & 0.20 & 0.27 & 0.14 & 0.07 & 3.3 & 3.0 & 1.1 & 0.9 \\
$\mathrm{~Pb}$ & 9.2 & 5.5 & 4.0 & 3.3 & 14.2 & 8.3 & 6.3 & 3.8 \\
$\mathrm{Br}$ & 0 & 0 & 3.5 & 0.9 & 0 & 0 & 5.5 & 1.8 \\
\hline
\end{tabular}

Table 2. Geometric mean mass $\left(\mu \mathrm{g} / \mathrm{m}^{3}\right)$ and elemental $\left(\mathrm{ng} / \mathrm{m}^{3}\right)$ concentrations in PM1 and PM10 fractions of atmospheric aerosol collected at Finokalia station and aboard the research vessel "AEGAIEO” during 25-29 July 2000.

\begin{tabular}{ccccc}
\hline & \multicolumn{2}{c}{ PM1 } & \multicolumn{2}{c}{ PM10 } \\
& Finokalia & Vessel & Finokalia & Vessel \\
\hline Mass & 17 & 20 & 46 & 53 \\
$\mathrm{Al}$ & 39 & 35 & 496 & 426 \\
$\mathrm{Si}$ & 294 & 167 & 2866 & 2838 \\
$\mathrm{~S}$ & 2705 & 2703 & 2913 & 3043 \\
$\mathrm{Cl}$ & 0 & 0 & 155 & 417 \\
$\mathrm{~K}$ & 109 & 87 & 455 & 468 \\
$\mathrm{Ca}$ & 62 & 25 & 1093 & 896 \\
$\mathrm{Ti}$ & 9 & 6 & 79 & 87 \\
$\mathrm{~V}$ & 7 & 13 & 11 & 18 \\
$\mathrm{Cr}$ & 1 & 1 & 1 & 1 \\
$\mathrm{Mn}$ & 2 & 2 & 16 & 16 \\
$\mathrm{Fe}$ & 80 & 51 & 800 & 828 \\
$\mathrm{Ni}$ & 2 & 6 & 3 & 7 \\
$\mathrm{Cu}$ & 1 & 1 & 2 & 2 \\
$\mathrm{Zn}$ & 9 & 10 & 15 & 20 \\
$\mathrm{Sr}$ & 0 & 0 & 5 & 4 \\
$\mathrm{~Pb}$ & 10 & 13 & 16 & 20 \\
$\mathrm{Br}$ & nd & nd & nd & nd \\
\hline
\end{tabular}

ern Greece (7 January 2001), air masses which had recirculated over northern Libya (8 January 2001) and arriving at Crete from the south, and air masses originating above the Atlantic Ocean and arriving with high wind speeds across the western Europe and southern Italy (9 January 2001).

Inverted distributions were integrated to obtain PM1 and PM10 elemental concentrations. Geometric mean mass and elemental concentrations in PM1 and PM10 fractions of atmospheric aerosols collected at Finokalia station during the summer and winter campaigns are compared in Table 1. As can be seen the winter values are considerably lower except for $\mathrm{Cl}$. Further, Table 2 shows a comparison of mass and elemental concentrations in PM1 and PM10 aerosols collected during corresponding days at Finokalia and aboard the "AEGAIEO". Both mass and elemental concentrations found at Finokalia and aboard the vessel are comparable with the exception of $\mathrm{Cl}, \mathrm{V}$, and $\mathrm{Ni}$.

Figures $4 \mathrm{a}-\mathrm{e}$ show the temporal variation of PM1 and PM10 for several elements ( $\mathrm{Si}, \mathrm{K}, \mathrm{Cl}, \mathrm{S}, \mathrm{V}$ ) characteristic for certain groups of elements and also for different types of the mentioned elemental size distributions. Figure 4a shows the time series of PM1 and PM10 for Si as a typical crustal element. It can be seen that PIXE analysis revealed another peak in the concentration of Si on the 12 of July 2000. According to backward trajectories and Meteosat pictures this increase was caused by Saharan dust. Figure $4 \mathrm{~b}$ shows the temporal variation of another crustal element potassium, which exhibited a bimodal distribution. Here the higher concen- 

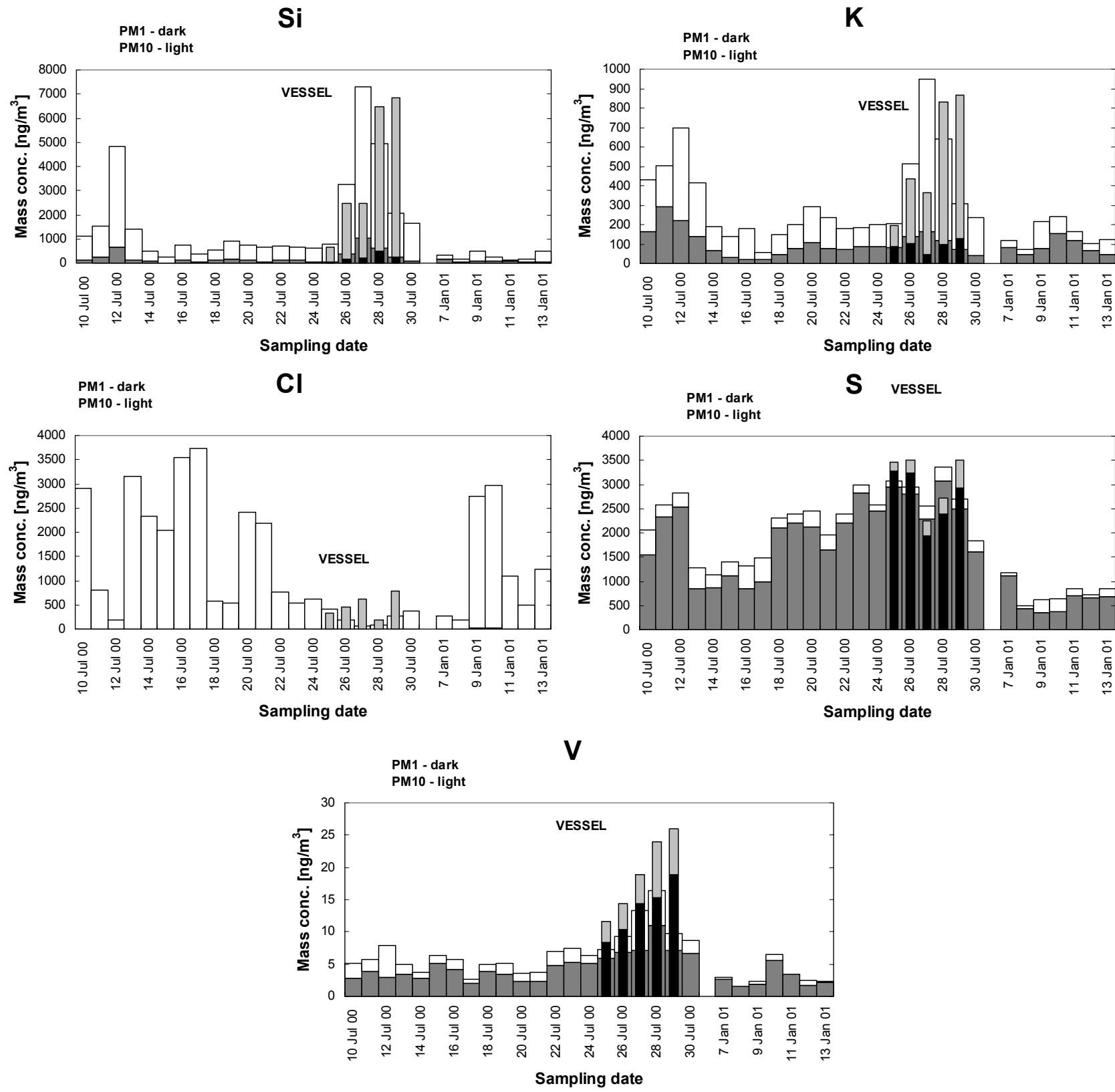

Fig. 4. Daily concentrations of (a) $\mathrm{Si}$, (b) $\mathrm{K},(\mathbf{c}) \mathrm{Cl}$, (d) $\mathrm{S}$, and (e) V in PM1 and PM10 at Finokalia and aboard of the research vessel "AEGAIEO".

trations correspond both to Saharan dust, where the potassium is present in illite (e.g. Ganor et al., 1991; Molinaroli, 1996), and to forest fires. This follows from satellite pictures showing forest fires in Greece and surrounding areas, which occurred at the beginning of the summer campaign, and from higher concentrations of potassium in the PM1 fraction found in the corresponding samples. The latter is typical for wood combustion (e.g. Valmari et al., 1998) and biomass burning (e.g. Jaffrezo et al., 1998). Figure 4c shows the temporal variation of chlorine. For chlorine we have not observed any specific dependence on the air mass trajectories, but rather on the velocity of air mass transport. Higher chlorine concentrations were observed for air masses which originated over the Atlantic Ocean and were transported with a high velocity across Europe (10, 13-17 July 2000, 9 and 10 January 2001) or originated above the western coast of the Black Sea (20 and 21 July 2000). Low chlorine concentrations were found during periods of calm weather. The origin of chlorine in atmospheric aerosol is mainly sea-salt particles produced by bursting of air bubbles at the ocean sur- 
face. The number of sea-salt particles can be approximated by an exponential function of the wind speed (Lovett, 1978; Monahan et al., 1986; Smith et al., 1993) and this dependence of marine element concentrations on the local wind speed has been observed in the Mediterranean (e.g. Bergametti et al., 1989a; Chabas and Lefèvre, 2000). Since we have not found any correlation with the local wind speed, the observed chlorine concentrations may also depend on distant marine source strength and long range transport to Crete. Figure $4 \mathrm{~d}$ shows the temporal variation of sulphur concentration. As can be seen, sulphur was predominantly found in submicron particles. Concentrations of sulphur determined in the PM1 and PM10 fractions by PIXE, correlated well with the concentrations determined in the soluble fraction by ion chromatography (Bardouki et al., 2003) with the regression slope close to unity. It is concluded that sulphur was present as sulphate. Lower concentrations were observed for air masses, which originated over the Ligurian Sea and the Mediterranean Sea to the west of Crete. Higher concentrations were observed for air masses arriving from the west coast of the Black Sea or from western Europe but later recirculated above the west coast of the Black Sea before arriving from the North. Figure 4d shows the seasonal variation in sulphur, with higher concentrations being observed during the summer. This is in agreement with other results from this region (Tsitouridou and Samara, 1993; Luria et al., 1996; Mihalopoulos et al., 1997; Danalatos and Glavas, 1999). Higher sulphate concentrations in the summer may be caused by higher phytoplanktonic activity producing gaseous dimethylsulphide that is later oxidised to methanesulphonic acid and sulphur dioxide (Finlayson-Pitts and Pitts, 2000) and larger conversion rates due to higher concentrations of oxidising species (Danalatos and Glavas, 1999). As found earlier at Finokalia, biogenic sulphur can account for 0.6 to $28.3 \%$ of the total non- sea-salt sulphate concentrations (Mihalopoulos et al., 1997) with higher values observed during the summer. Also, the long range transport of sulphates may have greater influence in summer due to rare precipitation events in the region during this period (Luria et al., 1996). In our case the non-sea-salt sulphate concentrations followed the ${ }^{222} \mathrm{Rn}$ variation and this indicates air of continental origin (Bardouki et al., 2003). This can be supported by similar behaviour of the time series found for sulphur and the anthropogenic elements $\mathrm{Cu}, \mathrm{Pb}$, and $\mathrm{Zn}$. The temporal variation of vanadium is shown in Fig. 4e. Vanadium appears to have a mixed origin, as it is produced by fuel oil combustion and also exists in mineral dust (Finlayson-Pitts and Pitts, 2000). As a result vanadium is found both in submicron and coarse particles. The contribution of oil combustion is clearly seen from the higher concentration of vanadium found aboard the boat, coming from emissions by other vessels cruising in the area and, on some occasions, from the exhaust stack of the "AEGAIEO". Also vanadium, from Saharan dust, increased its concentration towards the end of the summer campaign (Schütz and Rahn, 1982, Bonelli et al., 1996).
It follows that the concentration of trace elements in the central and eastern Mediterranean aerosol is a result of complex processes that depend on the transport of pollutants from their sources. This includes air mass transport, strength and spatial distribution of sources, precipitation scavenging by distant and local rain events, and for some elements such as halogens even on chemical reactions.

\section{Conclusions}

Size resolved aerosol samples were collected at Finokalia, a coastal site in Crete and aboard the research vessel "AEGAIEO" cruising the Aegean Sea during two periods in July 2000 and January 2001. Gravimetric analysis of samples yielded PM1 and PM10 temporal variations. The elemental composition of samples was determined by PIXE. The time series for PM1 and PM10 showed both daily and seasonal variation. The daily variation was caused mainly by air masses arriving at Crete from different directions including two incursions of Saharan dust. The seasonal variation was probably caused by precipitation scavenging, which is more frequent in winter. The elemental analysis showed practically monomodal distributions for crustal elements, chlorine, and sulphur. Sulphur has most of its mass in the submicron size range, crustal elements and chlorine in the supermicron fractions. Three elements $\mathrm{K}, \mathrm{V}$, and $\mathrm{Ni}$ exhibited bimodal distributions, due to anthropogenic and crustal sources. Higher concentrations of potassium in submicron particles corresponded to forest fires, and vanadium and nickel to oil combustion. High concentrations of vanadium and nickel in submicron particles, produced by fuel oil combustion, were found in samples collected aboard the research vessel. Anthropogenic elements $\mathrm{Cr}, \mathrm{Cu}, \mathrm{Pb}$, and $\mathrm{Zn}$ exhibited broad and arbitrary shaped distributions. Higher concentrations of these elements were found for air masses originating from the west coast of the Black Sea and advected across northern Greece and western Turkey. The time series for $\mathrm{Cu}$, $\mathrm{Pb}$, and $\mathrm{Zn}$, resemble the behaviour of sulphur, thus indicating similar sources.

Acknowledgements. This work was supported by the European Commission under grant ENVK2-1999-00052. The work is also partly supported by the Czech-Greek R\&D Cooperation, Kontakt No. 25.

\section{References}

Bardouki, H., Liakakou, H., Economou, C., Sciare, J., Smolík, J., Ždímal, V., Eleftheriadis, K., Lazaridis, M., and Mihalopoulos, N.: Chemical composition of size resolved atmospheric aerosols in the eastern Mediterranean during summer and winter, Atmos. Environ., 37, 195-208, 2003.

Bergametti, G., Dutot, A.-L., Buat-Ménard, P., Losno, R., and Remoudaki, E.: Seasonal variability of the elemental composition 
of atmospheric aerosol particles over the northwestern Mediterranean, Tellus, 41B, 353-361, 1989a.

Bergametti, G., Gomes, L., Remoudaki, E., Desbois, M., Martin, D. and Buat-Ménard, P.: Present transport and deposition patterns of African dust to the North-Western Mediterranean, In: Paleoclimatology and Paleometeorology: Modern and Past Patterns of Global Atmospheric Transport, edited by Leinen, M. and Sarthein M., Kluwer Academic Publishers, Dordrecht, pp. 227252, 1989b.

Bonelli, P., Braga Marcazzan, G.,M., and Cereda, E.: Elemental composition and air trajectories of African dust transported in northern Italy, The Impact of Desert Dust Across the Mediterranean, edited by Guerzoni, S. and Chester, R., Kluwer Academic Publishers, Dordrecht, pp. 275-283, 1996.

Chabas, A. and Lefèvre, R. A.: Chemistry and microscopy of atmospheric particulates at Delos (Cyclades-Greece), Atmos. Environ., 34, 225-238, 2000.

Chester, R., Nimmo, M., Alarcon, M., Saydam, C., Murphy, K. J. T., Sanders, S. G., and Corcoran, P.: Defining the chemical character of aerosols from the atmosphere of the Mediterranean Sea and surrounding regions, Oceanologica Acta, 16, 231-246, 1993.

Danalatos, D. and Glavas, S.: Gas phase nitric acid, ammonia and related particulate matter at a Mediterranean coastal site, Patras, Greece, Atmos. Environ., 33, 3417-3425, 1999.

Dulac, F., Buat-Ménard, P., Arnold, M., Ezat, U., and Martin, D.: Atmospheric input of trace metals to the western Mediterranean Sea: 1 . Factors controlling the variability of atmospheric concentrations, J. Geophys. Res., 92, 8437-8453, 1987.

Dulac, F., Buat-Ménard, P., Ezat, U., and Melki, S.: Atmospheric input of trace metals to the western Mediterranean: uncertainties in modelling dry deposition from cascade impactor data, Tellus, 41B, 362-378, 1989.

Erduran, M. S. and Tuncel, S. G.: Gaseous and particulate air pollutants in the northeastern Mediterranean Coast, Sci. Total Environ., 281, 205-215, 2001.

Finlayson-Pitts, B. J. and Pitts Jr., J. N.: Chemistry of the Upper and Lower Atmosphere, Theory, Experiments and Applications, Academic Press, San Diego, 2000.

Ganor, E., Foner, H. A., Brenner, S., Neeman, E., and Lavi, N.: The chemical composition of aerosols settling in Israel following dust storms, Atmos. Environ., 25A, 2665-2670, 1991.

Guerzoni, S., Correggiari, I., and Miserocchi, S.: Wind-blown particles from ships and land-based stations in the Mediterranean See: A review of trace metal sources, Water Poll. Res. Rep., 20, 377-386, 1990

Güllü, G., Ölmez, I., and Tuncel, G.: Temporal variability of atmospheric trace element concentrations over the eastern Mediterranean Sea, Spectrochimica Acta B, 55, 1135-1150, 2000.

Hacisalihoğlu, G., Balkaş, T. I., Tuncel, S. G., Herman, D. H., Ölmez, I., and Tuncel, G.: Trace element composition of the Black Sea aerosols, Deep-Sea Res., 38, S1255-S1266, 1991.

Hacisalihoǧlu, G., Eliyakut, F., Ölmez, I., Balkaş, T. I., and Tuncel, G.: Chemical composition of particles in the Black Sea atmosphere, Atmos. Environ., 26A, 3207-3218, 1992.

Havránek, V., Kučera, J., Horáková, J., Voseček, V., Smolík, J., Schwarz, J., and Sýkorová, I.: Matrix effects in PIXE analysis of aerosols and ashes, Biological Trace Elements Res., 71-72, 431-442, 1999.
Havránek, V., Voseček, V., Smolík, J., Schwarz, J., and Ždimal, V.: Analysis of Aerosol Samples by Energetic Ion Beam, CzechFinnish Aerosol Symposium, Report Series in Aerosol Science, No 56, pp. 47-51, Prague, Czech Republic, 23-26 May 2002.

Hillamo, R. E. and Kauppinen, E. I.: On the performance of the Berner low pressure impactor, Aerosol Sci. Technol., 14, 33-47, 1991.

Hillamo, R. E., Makela, T., Schwarz, J., and Smolík, J.: Collection characteristics of the model 25/0,018/2 Berner low pressure impactor, J. Aerosol Sci., 30(S1), 901-902, 1999.

Jaffrezo, J. L., Davidson, C. I., Kuhns, H. D., Bergin, M. H., Hillamo, R., Maenhaut, W., Kahl, J. W., and Harris, J. M.: Biomass burning signatures in the atmosphere of central Greenland, J. Geophys. Res., 103, 31 067-31 078. 1998.

Kubilay, N., Yemenicioglu, S., and Saydam, C.: Trace metal characterization of airborne particles from the northeastern Mediterranean, Fresenius Envir. Bull. 3, 444-448, 1994.

Kubilay, N., Yemenicioglu, S., and Saydam ,C.: Airborne material collections and their chemical composition over the Black Sea, Marine Pollution Bull., 30, 475-483, 1995.

Lovett, R. F.: Quantitative measurements of airborne sea-salt in the north Atlantic, Tellus, 30, 358-363, 1978.

Luria, M., Peleg, M., Sharf, G., Tov-Alper, D. S., Spitz, N., Ben Ami, Y., Gawii, Z., Lifschitz, B., Yitzchaki, A., and Seter, I.: Atmospheric sulfur over the east Mediterranean region, J. Geophys. Res., 101, 25 917-25 930, 1996.

Maenhaut, W., Ptasinski, J., and Cafmeyer, J.: Detailed mass size distributions of atmospheric aerosol species in the Negev desert, Israel, during ARACHNE-96, Nucl. Instrum. Meth. B, 150, 422427, 1999.

Mamane, Y., Ganor, E., and Donagi, A. E.: Aerosol composition of urban and desert origin in the Eastern Mediterranean, I. Individual particle analysis, Water Air Soil Pollut., 14, 29-43, 1980.

Migon, C., Morelli, J., Nicolas, E., and Copin-Montegut, G.: Evolution of total atmospheric deposition of $\mathrm{Pb}, \mathrm{Cd}, \mathrm{Cu}$ and $\mathrm{Zn}$ to the Ligurian Sea, Sci. Total Environ., 105, 135-148, 1991.

Migon, C., Alleman, L., Leblond, N., and Nicolas, E.: Evolution of atmospheric lead over the northwestern Mediterranean between 1986 and 1992, Atmos. Environ., 27A, 2161-2167, 1993.

Mihalopoulos, N., Stephanou, E., Kanakidou, M., Pilitsidis, S., and Bousquet, P.: Tropospheric aerosol ionic composition in the Eastern Mediterranean region, Tellus, 49B, 314-326, 1997.

Molinaroli, E.: Mineralogical characterisation of Saharan dust with a view of its final destination in Mediterranean sediments, In: The Impact of Desert Dust Across the Mediterranean (edited by Guerzoni, S. and Chester, R.), Kluwer Academic Publishers, Dordrecht, pp. 153-162, 1996.

Monahan, E. C., Spiel, D. E., and Spiel, K.: Oceanic whitecaps, Reidel, 1986.

Moulin, C., Lambert, C. E., Dayan, U., Masson, V., Ramonet, M., Bousquet, P., Legrand, M., Balkanski, Y. J., Guelle, W., Marticorena, B., Bergametti, G., and Dulac, F.: Satellite climatology of African dust transport in the Mediterranean atmosphere, J. Geophys. Res., 103, 13 137-13 144, 1998.

Sandroni, V. and Migon, C.: Significance of trace metal mediumrange transport in the western Mediterranean, Sci. Total Environ., 196, 83-89, 1997.

Schütz, L. and Rahn, K. A.: Trace-element concentrations in erodible soil, Atmos. Environ., 16, 171-176, 1982. 
Smith, M. H., Park, P. M., and Consterdine, I. E.: Marine aerosol concentration and estimated fluxes over seas, Q. J. R. Meteorol. Soc., 809-824, 1993.

Tsitouridou, R. and Samara, C.: First results of acidic and alkaline constituents determination in air particulates of Thessaloniki, Greece, Atmos. Environ., 27B, 313-319, 1993.

Valmari, T., Kauppinen, E. I., Kurkela, J., Jokiniemi, J. K., Sfiris, G., and Revitzer, H.: Fly ash formation and deposition during fludized bed combustion of willow, J. Aerosol Sci., 29, 445-459, 1998.
Wolfenbarger, J. K. and Seinfeld, J. K.: Inversion of aerosol size distribution data, J. Aerosol Sci., 21, 227-247, 1990.

World Meteorological Organization: Atmospheric transport of contaminants into the Mediterranean region, GESAMP Report and Studies, 26, 53, 1985.

Yatin, M., Tuncel, S., Aras, N. K., Ölmez, I., Aygün, S., and Tuncel, G.: Atmospheric trace elements in Ankara, Turkey: 1. factors affecting chemical composition of fine particles, Atmos. Environ., 23, 1305-1318, 2000. 